\title{
Screening of diseases transmissible by blood in recipients prior to transfusion at a university hospital in the Northeast of Brazil
}

\author{
Triagem de doenças transmissíveis por sangue em receptores de um hospital universitário no \\ Nordeste do Brasil, antes da transfusão
}

\author{
Cristina F. V. Carrazzone $e^{1,2,3}$ \\ Alinne F. A. Verçosa ${ }^{1}$ \\ Virginia M. B. Lorena ${ }^{1}$ \\ Myllena F. A. D. Melo ${ }^{1}$ \\ Raquel C. A. Machado ${ }^{1}$ \\ Maria B. D. A. Pinto ${ }^{2}$ \\ Ana M. Brito ${ }^{1,4}$ \\ Yara M. Gomes ${ }^{1}$
}

The Brazilian Ministry of Health has made tests for HIV1 and HIV2, HTLV I and $H T L V I I, H C V, H B V$, T. cruzi, T. pallidum and Plasmodium in endemic areas, mandatory for all blood collection bags used in the country. However, blood-borne infectious diseases are not investigated in blood recipients before transfusion. For this study, a serological evaluation of recipients before transfusion was carried out. Prior to transfusion, serum samples from 159 blood recipients were analyzed using the same tests used in the serological screening of blood donors. The blood recipients were divided into three groups: Group 1 (G1), patients who had never received blood, Group 2 (G2), patients who had received multiple transfusions and Group 3 (G3) one-off recipients. SPSS v. 8 was used for statistical analysis. Values of $p<0.05$ were taken to be significant. The results showed that 62 blood recipients tested positively for one or more blood-borne infectious diseases. In addition, several recipients were unaware of their serological status before the transfusion. The identification of bloodborne infectious diseases in recipients before transfusion could avoid the State being held responsible by recipients who were unaware that they were carriers of such diseases and only found out about their contamination after transfusion. Rev. bras. hematol. hemoter. 2006;28(1):24-27.

Key words: Serological screening; blood recipients; blood transfusion; hemotherapy.

\section{Introduction}

Hemotherapy has proved capable of making an impact on developing and adopting new technologies aiming to minimize the risk of transmission of blood-borne infections through blood transfusions. ${ }^{1,2}$ In the past, the selection of blood donors was considered the most important factor in reducing infections through blood transfusion. ${ }^{3}$ With the introduction of serological tests in the blood banks, there was an enormous decrease in the most commonly transmitted infectious diseases through blood (HIV, HBV, HCV, HTLV-
I/II, Chagas' disease and syphilis). ${ }^{4}$ Furthermore, hemovigilance has been of great importance in: i) ensuring surveillance of blood transfusion activities, ii) collecting data on (serious) sequelae of blood transfusion, iii) providing information for health policy-makers, iv) improving transfusion standards, v) assisting in the drawing up of guidelines in the field and vi) improving the safety and quality of the entire transfusion process. ${ }^{5}$ Nevertheless, blood-born infectious diseases are still a problem, because infected blood is collected before the appearance of serological markers of infection, i.e. during the immunological window period. ${ }^{1,6,7}$

\footnotetext{
${ }^{1}$ Centro de Pesquisas Aggeu Magalhães-CPqAM/Fundação Oswaldo Cruz -Fiocruz - Recife-PE.

${ }^{2}$ Fundação Hemope - Recife-PE.

${ }^{3}$ Hospital Universitário Oswaldo Cruz - HUOC/Universidade de Pernambuco - UPE - Recife-PE.

${ }^{4}$ Faculdade de Ciências Médicas - Universidade de Pernambuco - UPE - Recife-PE.
}

Correspondence: Yara M. Gomes

Departamento de Imunologia, Centro de Pesquisas Aggeu Magalhães/Fiocruz

Av. Moraes Rego s/n, Cidade Universitária

50670-420 - Recife-PE - Brazil

Phone: 55-81-2101-2559 - Fax: 55-81-34532449

E-mail: yara@cpqam.fiocruz.br 
Although serological screening of the blood donor is obligatory, there is no standard for identifying blood-borne infectious diseases in blood recipients (BRs) before transfusion.

The aim of the present study was to carry out a serological evaluation of BRs at a University Hospital in the Northeast of Brazil, in order to investigate the presence of infectious diseases transmitted through blood in those recipients prior to transfusion.

\section{Patients and Methods}

From February to May 2003 information (the history of transfusions and knowledge regarding the patient's serum) and blood samples were collected from 159 BRs (age-range: 1-82 years), before transfusion, in the Hospital Universitário Oswaldo Cruz (HUOC) situated in Recife, a city in the Northeast of Brazil. The samples submitted to immunohematological tests ( $\mathrm{ABO}$ and Rh compatibility) were stored at $-20^{\circ} \mathrm{C}$ before being used for the same screening assays as blood donors to detect Trypanosoma cruzi, HIV, HTLV-I/II, Treponema pallidum, HBV and HCV.

The BRs that tested positive during these screening assays were divided into three groups: Group 1 (G1), patients who had never received blood, Group 2 (G2), patients who had received multiple transfusions and Group 3 (G3) oneoff recipients. One-off recipients are taken to be individuals that require a one-off transfusion for multiple trauma, burns, major surgery and the such like. Recipients receiving multiple transfusions, on the other hand, are patients (such as leukemic, thalassemic and hemophiliac patients) who require regular transfusions.

The study protocol was approved by the Ethics Committee of the Centro de Pesquisas Aggeu Magalhães of the Fundação Oswaldo Cruz/Fiocruz (Ministry of Health, Brazil). Written informed consent was obtained from all individuals.

Screening tests for blood donors were carried out on all BRs according to the manufacturer's instructions. To detect anti-T. cruzi antibodies the Chagatek Elisa kit (Biomérieux, Argentina S.A.) was used. Anti-HIV 1, antiHIV 2 antibodies and sub-type $\mathrm{O}$ were detected by means of two ELISAs using the Vironostika HIV Uni-Form II O kit (Biomérieux, Holanda) and Murex HIV-1.2.O. (Murex Biotech Limited, UK). Anti-HTLV I/II antibodies were detected by means of Elisa using the Murex HTLV I+II (Murex Biotech Limited, UK). The detection of anti-HCV antibodies was carried out using the Murex anti-HCV kit (version 4.0) (Murex Biotech S.A., South Africa). Anti-T. pallidum antibodies were detected by means of VDRL using the VDRL-BRÁS kit (Laborclin, Brazil). Anti-HBc antibodies were detected by means of two Elisas using the Ortho Antibody for HbsAg Elisa (Ortho-ClinicalDiagnostic, Inc., New Jersey, USA) and Monolisa anti-
HBc Plus (Bio-Rad, France). The positive samples were retested in duplicate using the same kit and the positive BRs were referred for appropriate treatment.

The $\chi^{2}$ test was calculated using the SPSS v. 8 Statistical Package for Social Sciences Incorporation, US. Values of $\mathrm{p}<0.05$ were taken to be significant.

\section{Results and Discussion}

The serological screening of blood donors does not provide a $100 \%$ guarantee of protection against the possible transmission of infectious and contagious agents. According to the National Health Surveillance Agency-Anvisa [8], the Brazilian Ministry of Health, tests for HIV 1 and HIV2, HTLV I and HTLV II, HCV, HBV, T. cruzi, T. pallidum and Plasmodium in endemic areas are mandatory for all blood collection bags used in Brazil and samples from blood donors must be stored for at least six months.

So far as BRs are concerned, the recommendation is that immunohematological tests prior to transfusion, such as $\mathrm{ABO} / \mathrm{Rh}$ classification, irregular antibody titer, and compatibility tests, must be carried out. In this case, the samples from BRs need to be stored for only 10 days. ${ }^{8}$ Considering that some pathologies in donors, even when detected, can still be transmitted to the recipients and can remain asymptomatic for several decades, a study of the causes and effects between recipients and their respective donors is necessary.

In this study, a serological evaluation of BRs before the transfusion was carried out. The results showed that, among 159 BRs, 62 were positive for one or more bloodborne diseases. As shown in Fig. 1, 75 tested positive mainly for HBV. These results led us to evaluate the percentage of positive reactions in BRs for one or more pathogenic agent (PA) analyzed. Fifty-two (83.9\%) BRs tested positive for at least one of the PAs, 7 (11.3\%) for two PAs and 3 (4.8\%) for three PAs. No reactions were observed for HTLV I-II.

On analysis of the response of the groups regarding previous transfusions, the results showed that 38 (62.3\%)

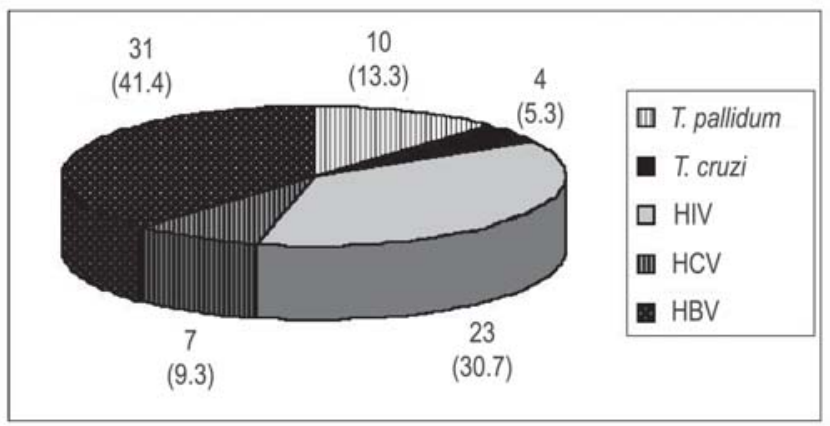

Figure 1. Number of positive reactions in blood recipients to T. pallidum, T. cruzi, HIV, HCV and HBV ( ) = Percentage of positive reactions 
were from G1, 2 (3.3\%) from G2 and 21 (34.4\%) from G3. A significant difference $(\mathrm{p}<0.001)$ was observed in all groups. When the BRs from these groups were investigated concerning previous knowledge of their serology, $57.6 \%$ of G1, $100 \%$ of G2 and $63.2 \%$ of G3 were unaware of their serological status before the transfusion. No significant difference $(p=0.477)$ was observed regarding these results.

These data constitute a warning to health authorities and demonstrate the need for more extensive evaluations prior to transfusion tests, justifying the recommendation of Anvisa, ${ }^{9}$ which states that, "only if specific tests were carried out on the recipients before blood transfusion, would it be possible to assume a correlation between a blood transfusion and the contamination". Another aspect to be considered, regarding the possibility of infection subsequent to transfusion, is the weakness of the federal government itself when it claims that it is its legal "duty to guarantee safe transfusion for all citizens", without, however, establishing any procedures for providing previous knowledge of the BRs. The results of the serological evaluation of BRs from HUOC/ UPE, with $38.9 \%$ showing a positive reaction for at least one of the tests, corroborate this concern.

Insufficient data is available to describe accurately the types of patients who currently receive blood or blood components. An investigation of transfusion-transmitted infection in recipients of over 20,000 units of blood has show that a considerable proportion of patients have preexisting infections and many of them are unaware of this fact. ${ }^{1}$ According to Regan et al ${ }^{10}$ it is useful to know the profile of patients who receive blood components for a number of reasons: i) When a new test for an infectious agent is first introduced, donors who test positive would be identified. Blood previously donated by all these donors may need to be traced and the recipients of all components identified, so that they can be tested and advised appropriately. Similarly, when considering potentially new infections, which might be transmitted by blood, an understanding of the breakdown of patients who receive blood components would be useful. ii) If there is a potential shortage of blood, knowledge of the typical casemix of recipients may be helpful in order to determine areas for possible reduction of use and alternatives to blood and to access which patients might be most severely affected if the shortage is severe. iii) When there are new areas of growth in blood use, such as new surgical procedures or political initiatives, it would be possible to estimate the impact on the demand for blood. ${ }^{10,11}$

These facts point to the need for establishing mechanisms capable of detecting the presence of bloodborne pathogens in BRs prior to transfusion. ${ }^{12}$ The identification of blood-borne infectious diseases in BRs before transfusion could avoid the federal government being held responsible by BRs who were unaware that they were carriers of these diseases and who only discovered about their contamination after transfusion. Furthermore, this could decrease the burden of responsibility generated when a study of cause and effect between recipients and their respective donors is carried out.

\section{Resumo}

O Ministério da Saúde brasileiro determina a realização de testes sorológicos para HIV 1 e 2, HTLV I e II, HCV, HBV, T. cruzi, T. pallidum e Plasmodium nas áreas endêmicas, em todas as bolsas de coleta de sangue utilizadas no País. Entretanto, as doenças infecciosas transmissíveis através do sangue não são investigadas nos receptores de sangue (RS) antes da transfusão. Neste estudo, realizamos uma avaliação sorológica dos RS anterior à transfusão. Amostras de soro de 159 RS foram analisadas aplicando-se os mesmos testes utilizados na triagem sorológica dos doadores de sangue. Os RS foram divididos em três grupos: Grupo 1 (G1), pacientes que nunca receberam sangue, Grupo 2 (G2), pacientes politransfundidos e Grupo 3 (G3) receptores eventuais. Para a análise estatística utilizou-se o programa SPSS v.8. Valores de $p<0,05$ foram considerados significantes. Os resultados mostraram que $62 \mathrm{RS}$ apresentaram positividade para uma ou mais doenças infecciosas transmissíveis pelo sangue. Além disso, vários RS desconheciam seu estado sorológico anterior à transfusão. A identificação de doenças infecciosas transmissíveis pelo sangue em RS anterior à transfusão poderia evitar a responsabilidade do Estado pelos $R S$ que desconheciam ser portadores de tais doenças e apenas tiveram conhecimento de sua contaminação após a transfusão. Rev. bras. hematol. hemoter. 2006;28(1):24-27.

Palavras-chave: Triagem sorológica; receptores de sangue; transfusão sangüínea; hemoterapia.

\section{Acknowledgments}

This study was funded in part by the Conselho Nacional de Desenvolvimento Científico e Tecnológico (CNPq) and Fundação de Amparo à Pesquisa do Estado de Pernambuco (Facepe). Yara M. Gomes receives a research fellowship from CNPq. Alinne F.A. Verçosa and Virginia M.B. Lorena received Capes MSc scholarships while participating in the study.

\section{References}

1. Regan FAM, Hewitt P, Barbara JAJ. Prospective investigation of transfusion transmitted infection in recipients of over 20000 units of blood. BMJ 2000; 320:403-406.

2 .Regan F, Taylor C. Recent developments. Blood transfusion medicine. BMJ 2002; 325:143-147.

3. Amorin MC, Capiberibe I, Barbosa S et al. Recruitment strategies to change the profile of blood donors in northeast of Brazil of Recife. Rev Paul Med 1992;110:18.

4. Tosti ME, Solinas S, Prati D et al. An estimate of the current risk of transmitting blood-borne infections through blood transfusion in Italy. $\mathrm{Br}$ J Haematol 2002;117:215-219. 
5. Faber JC. Worldwide overview of existing haemovigilance systems. Transf Apheresis Sci 2004;31:99-110.

6. Linden JV. Error contributes to the risk of transmissible disease (letter). Transfusion 1994;34:1.016.

7. Busch MP, Kleinman SH, Jackson B et al. Committee report. Nucleic acid amplification testing of blood donors for transfusion-transmitted infectious disease: Report of the Interorganizational Task Force on Nucleic Acid Amplification Testing of Blood Donors. Transfusion 2000;40:143-159.

8. Agência Nacional de Vigilância Sanitária (Anvisa). Sangue e hemoderivados. Legislação. Brazilian Ministry of Health. Site (http://elegis.bvs.br/leisref/public/showAct.php?id=371), 2004.

9. Agência Nacional de Vigilância Sanitária (Anvisa). Manual Técnico de Hemovigilância, Brazilian Ministry of Health, 2003.

10. Regan F. New donors, new recipients - who gets what in 2003? Transfus Clin Biol 2004;11:53-56.
11. Carrazzone CFV, Verçosa AFA, Lorena VMB et al. Avaliação do perfil sociodemográfico dos receptores de sangue do Hospital Oswaldo Cruz da Universidade de Pernambuco. An Fac Med Univ Fed Pernamb 2003; 48: 124-127.

12. Carrazzone CFV, Brito AM, Gomes YM. Importância da avaliação sorológica pré-transfusional em receptores de sangue. Rev Bras Hematol Hemoter 2004;26:93-98.

Avaliação: Editor e dois revisores externos.

Conflito de interesse: não declarado

Recebido: 06/08/2005

Aceito após modificações: 26/11/2005

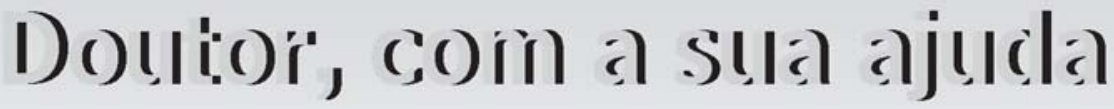

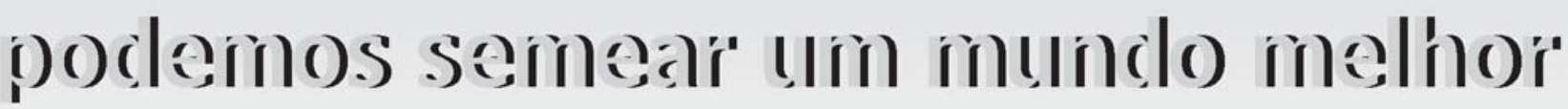 Participe do fortalecimento do maior programa público de transplantes do mundo. Notifique os casos de possíveis doadores à Central de Transplantes de seu estado.
}

\author{
Mais informações no site www.saude.gov.br/transplantes \\ Coordenação Geral do \\ Sistema Nacional de Transplantes/Ministério da Saúde
}

